\title{
Shox2 Regulates the Pacemaker Gene Program in Embryoid Bodies
}

\author{
Sherin I. Hashem, ${ }^{1}$ May L. Lam,, Shirley S. Mihardja, ${ }^{2}$ Steven M. White,, ${ }^{1, *}$ \\ Randall J. Lee, ${ }^{2}$ and William C. Claycomb ${ }^{1}$
}

The pacemaker tissues of the heart are a complex set of specialized cells that initiate the rhythmic heartbeat. The sinoatrial node (SAN) serves as the primary pacemaker, whereas the atrioventricular node can serve as a subsidiary pacemaker in cases of SAN failure or block. The elucidation of genetic networks regulating the development of these tissues is crucial for understanding the mechanisms underlying arrhythmias and for the design of targeted therapies. Here we report temporal and spatial self-organized formation of the pacemaker and contracting tissues in threedimensional aggregate cultures of mouse embryonic stem cells termed embryoid bodies (EBs). Using genetic marker expression and electrophysiological analyses we demonstrate that in EBs the pacemaker potential originates from a localized population of cells and propagates into the adjacent contracting region forming a functional syncytium. When Shox2, a major determinant of the SAN genetic pathway, was ablated we observed substantial slowing of spontaneous contraction rates and an altered gene expression pattern including downregulation of HCN4, Cx45, Tbx2, Tbx3, and bone morphogenetic protein 4 (BMP4); and upregulation of Cx40, Cx43, Nkx2.5, and Tbx5. This phenotype could be rescued by adding BMP4 to Shox2 knockout EBs in culture from days 6 to 16 of differentiation. When wild-type EBs were treated with Noggin, a potent BMP4 inhibitor, we observed a phenotype consistent with the Shox 2 knockout EB. Altogether, we have generated a reproducible in vitro model that will be an invaluable tool for studying the molecular pathways regulating the development of cardiac pacemaker tissues.

\section{Introduction}

$\mathrm{T}$ HE CARDIAC PACEMAKER and conduction system is a highly specialized system that initiates and coordinates the rhythmic heartbeat. The sinoatrial node (SAN) is the primary pacemaker of the heart and is responsible for generating the electrical impulse [1]. The atrioventricular node (AVN) is responsible for delaying the electrical impulse to allow for proper ventricular filling [2]. The AVN can also serve as a subsidiary pacemaker in conditions of SAN failure or block $[3,4]$. Although embryonic stem (ES) cells have been extensively used for generating mouse models for studies of the development of the cardiac conduction system (CCS) [5-11], their application as in vitro models for studying the development of this intricate system has been limited. Using the three-dimensional (3D) embryo-like embryoid body (EB) differentiation system, we and others were able to generate a reproducible cardiomyocyte system with electrical excitability and visible spontaneous contractions [12-15]. Cells isolated from the spontaneously contracting region within an EB display morphological, molecular, and functional properties of cardiomyocytes [14-19]. These cardiomyocytes are organized within EBs forming a functional syncytium containing all specialized cardiac cell types such as atrial-like, ventricularlike, sinoatrial nodal-like, and Purkinje fiber-like cells $[12,17,20]$. Moreover, cardiomyocytes that were enzymatically isolated from EBs at different stages of development demonstrated a transition from primitive pacemaker-like cells to more terminally differentiated chamber myocardium-like cells, simulating what occurs in vivo during heart development $[12,21,22]$. Accordingly, cardiomyocyte differentiation in EBs is not limited to the generation of isolated cardiomyocytes but rather to the development of a functionally integrated system containing a putative SAN [13]. This system can provide an invaluable opportunity to generate in vitro models that can be used to identify, genetically modify, and study the development of the specialized cells of the CCS.

Shox2, a member of the short stature paired-homeodomain family of transcription factors, is expressed early in development and is restricted to the sinus venosus myocardium including the SAN and the venous valves of embryonic hearts $[6,23]$. Shox 2 activates the SAN gene program by inhibiting

\footnotetext{
${ }^{1}$ Department of Biochemistry and Molecular Biology, Louisiana State University Health Sciences Center, New Orleans, Louisiana.

${ }^{2}$ Department of Medicine, Cardiovascular Research Institute, Eli and Edythe Broad Center of Regeneration Medicine and Stem Cell Research, University of California, San Francisco, San Francisco, California.

${ }^{*}$ Current affiliation: Office of Cook County Medical Examiner, Chicago, Illinois.
} 
chamber myocardial cell differentiation through the inhibition of the myocardial transcription factor $\mathrm{Nkx} 2.5[6,24]$. This in turn results in the expression of the T-box transcription factor Tbx3, which is responsible for executing the pacemaker gene program $[25,26]$. Tbx3 activation results in the upregulated expression of the nodal genes $\mathrm{HCN} 4$ and $\mathrm{Cx} 45$, and the inhibition of the chamber myocardial genes $A N F, C x 40$, and $C \times 43[25,26]$. Shox 2 null mice die during mid-gestation due to failure of the development of the SAN $[6,23]$. The SAN region in Shox $2^{-1-}$ hearts exhibits reduction in Tbx3 and HCN4 expression levels, and ectopic expression of Cx40, ANF and Nkx2.5 [6]. In addition, Shox2 regulates the expression of bone morphogenetic protein 4 (BMP4) in the SAN region [27]; however it has not been determined whether BMP4 is involved in the SAN pacemaker genetic pathway. We hypothesize that the CCS develops in a self-organized manner in 3D ES cell cultures and that these EB cultures can be used to study the pacemaker gene program that is activated by Shox 2 .

\section{Materials and Methods}

\section{Culture of ES cells and generation of EBs}

The mouse ES cell lines J1 cGATA6-RFP, and CJ-7 Shox $2^{+/+}$ Shox $2^{\text {lacZ/+ }}$, and Shox $2^{\text {lacZ/lacZ }}$ were cultured in growth medium supplemented with $15 \%$ fetal bovine serum (FBS), $0.1 \mathrm{mM} \beta$-mercaptoethanol (BME), $1 \%$ nonessential amino acid stock, and $1 \%$ penicillin/streptomycin, containing $10^{3}$ $\mathrm{U} / \mathrm{mL}$ leukemia inhibitory factor (LIF; Millipore). We used a hanging drop technique to generate EBs as previously described [12]. Each drop contained 500 cells in $20 \mu \mathrm{L}$ of differentiation medium (growth medium supplemented with $10 \%$ FBS and containing no LIF). The EBs were plated on day 5 of differentiation. Shox $2^{\text {lacZ/lacZ }}$ and Shox $2^{+/+}$EBs were treated with BMP4 and Noggin (R\&D Systems), respectively, at a concentration of $25 \mathrm{ng} / \mathrm{mL}$ from days 6 to 16 of differentiation. All cultures were in a humidified atmosphere of $95 \%$ air $5 \% \mathrm{CO}_{2}$ at $37^{\circ} \mathrm{C}$.

\section{Fluorescent live imaging}

EBs were incubated in medium containing $20 \mu \mathrm{M}$ fluorescein digalactoside (FDG-C12; Molecular Probes) for $20 \mathrm{~min}$ at $37^{\circ} \mathrm{C}$. The samples were washed with phosphatebuffered saline (PBS) and incubated for $1 \mathrm{~h}$ in differentiation medium. LacZ reporter expression was imaged using a FITC filter. For visualization, a Nikon (Eclipse TE300) microscope was used. Images (fluorescent and phase contrast) were captured using a digital camera (Roper Scientific) and were analyzed using MetaMorph software (version 5.0 v6; Molecular Devices).

\section{Immunohistochemistry}

Whole mount EBs were fixed in $4 \%$ paraformaldehyde for $15 \mathrm{~min}$ at room temperature. For $\beta$-galactosidase detection in fixed EBs, an in situ $X$-gal assay was performed using a $\beta$ galactosidase staining kit (Stratagene) following the manufacturer's protocol. Samples were then permeablized for 10 min with $0.4 \%$ Triton X-100 and then incubated with the primary antibody for $1 \mathrm{~h}$. Mouse monoclonal anti-titin (Abcam; 1:50 dilution), rabbit polyclonal anti-Cx45 (Millipore; 1:200 dilution), and goat monoclonal anti-HCN4 (Santa
Cruz; 1:400 dilution) antibodies were used. After multiple washes with PBS, samples were incubated in the appropriate secondary antibodies for $45 \mathrm{~min}$. Images were acquired with a Leica DM IRE2 inverted epifluorescent confocal microscope (Leica, Heerbrugg) or by a digital camera connected to a Nikon Microphot-SA microscope.

\section{Physical separation of Shox2 area from contracting region}

A scalpel blade was lowered between the lacZ-reporter region and the contracting region of an EB, and quickly pulled across the area to generate a clean cut completely separating the two regions without tissue destruction. The contractions were counted before and after the separation as previously reported [13]. Controls were generated by inducing a cut on the side opposite the contracting region.

\section{Quantitative reverse transcriptase-polymerase chain reaction}

Total RNA isolation, reverse-transcription, and quantitative reverse transcriptase-polymerase chain reaction (qRTPCR) were performed as previously described [28]. The primers used are provided in Table 1. Cycle thresholds (CT) were recorded and the $2^{-\Delta \Delta C T}$ algorithm was used to analyze the relative changes in gene expression as previously described [29].

\section{Culture and transfection of $H L-1$ cells}

HL-1 cells were cultured as previously described [30]. For transfection experiments, HL- 1 cells at $50 \%$ confluence were transfected with pShox2a-IRES-DsRed or pIRES-DsRed (empty vector) (kindly provided by Dr. YiPing Chen, Tulane University) using lipofectamine LF2000 (Invitrogen) according to the manufacturer's protocol. HL-1 cells transfected with the pShox2a-IRES-DsRed were cultured in medium with or without Noggin treatment at $25 \mathrm{ng} / \mathrm{mL}$ concentration. Total RNA was collected $48 \mathrm{~h}$ after transfections as previously described [28].

\section{Generation of GATA6 aggregates and coculture}

GATA6 nodal cells [13] were cultured in differentiation medium and passaged every 4 days. We used a hanging drop technique [12] to generate GATA6 cell aggregates. Each $30 \mu \mathrm{L}$ drop contained 400 cells in differentiation medium. After 4 days, the GATA6 nodal cell 3D aggregates were added to 2D HL-1 cell monolayer cultures. The cocultures were left to grow for an additional 1-3 days.

\section{Multielectrode array analysis}

Samples were plated onto a $50 \times 50 \mathrm{~mm}$ glass slide that has an embedded $1.4 \times 1.4 \mathrm{~mm}$ matrix of 60 titanium nitridegold contact electrodes with an interelectrode distance of $200 \mu \mathrm{m}$. Spontaneous electrical activity in coculture samples and in EBs was recorded at $10 \mathrm{kHz}$. Temperature was kept at $37^{\circ} \mathrm{C}$. Analysis of the recordings was done using the MC_Rack (Multi-Channel Systems) program and a customized toolbox programmed for MATLAB. The following parameters were investigated: interspike interval (ISI) and 
Table 1. Primer Sequences Used for Quantitative Reverse Transcriptase-Polymerase Chain Reaction

\begin{tabular}{|c|c|c|c|c|c|}
\hline Gene & Forward primer & Reverse primer & $\begin{array}{c}\text { Annealing } \\
\text { temperature } \\
\left({ }^{\circ} \mathrm{C}\right)\end{array}$ & $\begin{array}{l}\text { Expected } \\
\text { size }\end{array}$ & $\begin{array}{c}\text { Obtained } \\
\text { size }\end{array}$ \\
\hline GAPDH & ATCAAGAAGGTGGTGAAGCAG & GAGTGGGAGTTGCTGTTGAAGT & 57 & 104 & 104 \\
\hline Shox2 & ACCAATTTTACCCTGGAACAAC & TCGATTTTGAAACCAAACCTG & 60 & 141 & 141 \\
\hline BMP4 & ACAGCGGTCCAGGAAGAAGAAT & TGAGGTGATCAGCCAGTGGAAA & 60 & 155 & 155 \\
\hline Nkx2.5 & TTAGGAGAAGGGCGATGACT & AGGTCCGAGACACCAGGCTA & 58 & 141 & 141 \\
\hline $\mathrm{Tb} \times 3$ & AGGAGCGTGTCTGTCAGGTT & GCСАTTAССТССССААТTTT & 60 & 218 & 218 \\
\hline $\operatorname{Tb} 2$ & GGGTCATCTGCTAGCCTCGG & TATGCTGGGAGAGGTGGAAC & 62 & 152 & 152 \\
\hline Tbx5 & ATGGTCCGTAACTGGCAAAG & TTCGTCTGCTTTCACGATG & 60 & 211 & 211 \\
\hline $\mathrm{C} \times 40$ & CCTGAAACGTCCCTGTGTTT & TGAACAGGACAGTGAGCCAG & 62 & 139 & 139 \\
\hline Cx43 & GAACACGGCAAGGTGAAGAT & GAGCGAGAGACACCAAGGAC & 60 & 247 & 247 \\
\hline Cx45 & AGGCTGTCCTTGGTCAGAGA & TGTAACTCCAGTTCCAGGGG & 60 & 274 & 274 \\
\hline HCN4 & CTTCTGCTGTGTCACTGGGA & ATACTGCTTCССCCAGGAGT & 60 & 120 & 120 \\
\hline$\beta$-Galactosidase & TAGCGATAACGAGCTCCTGCA & CCTGACTGGCGGTTAAATTGC & 60 & 329 & 329 \\
\hline
\end{tabular}

BMP4, bone morphogenetic protein 4; Cx, connexin; HCN4, hyperpolarization-activated cyclic nucleotide-gated channel 4.

the decay of the extracellular potential (time from the onset of the field potential (FP) to the largest negative peak $=\mathrm{T}_{\min }$ ) $[31,32]$ at each electrode exhibiting electrical activity. ISI is a reliable measurement of the beating frequency. $\mathrm{T}_{\min }$ in relation to electrode position was used to create an activation map, which allowed assessment of the propagation of the electrical signal. After recording the multielectrode array (MEA) measurements the cells cultured on the MEAs were imaged using both phase contrast and fluorescence microscopy to correlate the EB position in relation to the activation map.

\section{Calcium imaging}

Cocultures of GATA6 cell aggregates and HL-1 cells were incubated in PBS containing $10 \mu \mathrm{M}$ of Calcium Green (Molecular Probes) for $30 \mathrm{~min}$ at $37 \mathrm{C}$. Samples were then washed with PBS and incubated for $1 \mathrm{~h}$ in differentiation medium. Images were acquired using a Nikon (Eclipse TE300) microscope and a digital camera, and they were analyzed using MetaMorph software.

\section{Generation of Shox2 homozygous knockout ES cells}

We used a technique previously described by Mortensen to generate Shox $2^{\text {lacZ/lacZ }}$ ES cells from Shox $2^{\text {lacZ/+ }}$ ES cells [33]. Briefly, Shox $2^{\text {lacz/+ }}$ ES cells were cultured in growth medium supplemented with $8-10 \mathrm{mg} / \mathrm{mL}$ of G418 (Invitrogen) for 10 days. The few surviving cells were allowed to grow in growth medium without G418. Genotyping was performed by genomic PCR. We used an Illustra ${ }^{\mathrm{TM}}$ tissue and cells genomic prep MiniSpin Kit (GE Healthcare) to extract total DNA, following the manufacturer's protocol. PCR using the primers in Table 2 was performed, and PCR products were separated by agarose gel electrophoresis.

\section{Statistical analysis}

Student's $t$-test and GraphPad Prism version 6 were used for statistical analysis. Data are expressed as mean \pm standard derivation or standard error of mean. $P$-values $<0.05$ were considered significant.

\section{Results}

\section{Cardiac pacemaker cells and working myocytes form a functional syncytium in EBs}

To assess whether the differentiating pacemaker cells and working cardiomyocytes form a functional electrical syncytium in EBs, we examined contracting EBs using an MEA system. By using a $1.5 \mathrm{~kb}$ cGATA6 minimal enhancer to genetically delineate differentiating pacemaker cells in EBs [13], we observed that in all of the EBs examined $(n>100)$ the reporter-positive (GATA6-RFP) cells organized into a distinct cluster as opposed to being diffusely scattered within an EB. The reporter-positive cell cluster was always located adjacent to the contracting region in $100 \%$ of the spontaneously contracting EBs examined (Fig. 1B). The FP waveforms recorded by an MEA system indicated that spontaneous depolarizations originated from within the fluorescent GATA6-RFP cell cluster and propagated into the surrounding spontaneously contracting region of the EB

Table 2. Primer Sequences Used for Genomic Polymerase Chain Reaction

\begin{tabular}{|c|c|c|c|c|}
\hline Region amplified & Forward primer & Reverse primer & $\begin{array}{c}\text { Expected } \\
\text { size }\end{array}$ & $\begin{array}{c}\text { Obtained } \\
\text { size }\end{array}$ \\
\hline Mutant Shox2 allele & AGAGGCTATTCGGCTATGA & AGCCATGATGGATACTTTCTCG & 300 & 300 \\
\hline Wild-type Shox2 allele & GGTCCGACTTCGCCTCTGCTTGAT & CTTGCCGCGCCCTTTAACCGAGAC & 520 & 520 \\
\hline
\end{tabular}




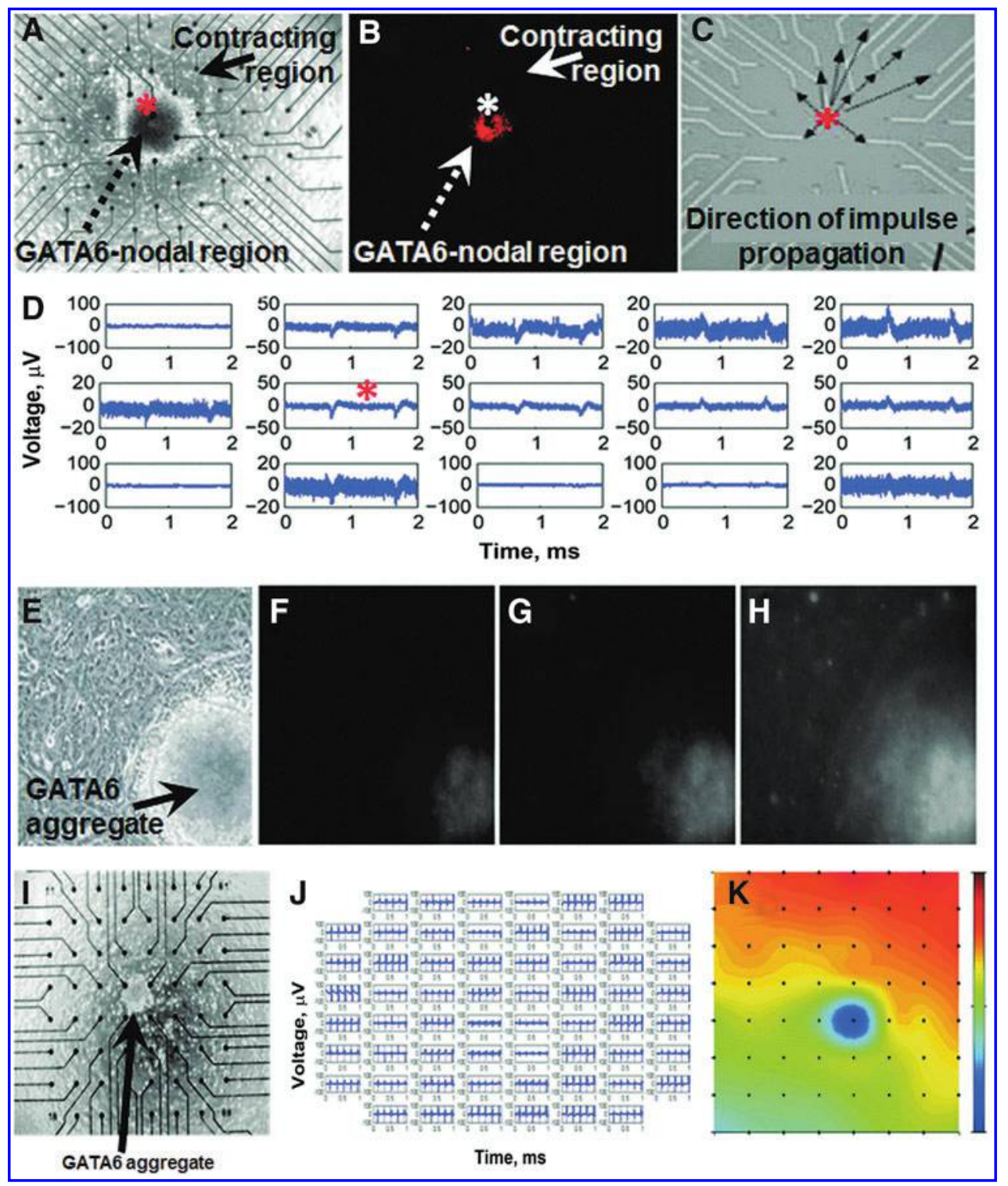

FIG. 1. Cardiac pacemaker and contracting myocytes form a functional syncytium in EBs. (A-D) Spontaneous electrical activity recorded from a GATA6-RFP EB that is centered on an MEA. Activity is recorded 2 days after the onset of visible contractions. The electrode of the MEA that represents the initiation point of the electrical activity is marked by an asterisk. (A, B) The solid arrow points to the contracting region, and the dashed arrow points to the GATA6-RFP fluorescent region of the EB. (C) The head of each arrow points to an individual electrode where an active FP was recorded in (A). The direction of the arrows depicts the direction of impulse propagation from the initiation point. (D) FPs recorded at electrodes surrounding the fluorescent region and the nearby contracting area. (E-H) A GATA6 nodal cell aggregate cocultured for 2 days on a 2D monolayer of HL-1 cells. (E) Phase contrast image and (F-H) sequential frames of digital stream images acquired using fluorescence microscopy following incubation of cocultures of nodal cell aggregates and HL- 1 cells with a fluorescent, calcium-sensitive dye. Free intracellular calcium is indicated as white in the images. (I) Phase contrast micrograph of a GATA6 nodal cell aggregate $18 \mathrm{~h}$ after plating in the center of an MEA on top of a $2 \mathrm{D}$ monolayer of HL-1 cells. (J) FPs recorded from this MEA 2 days after the nodal cell aggregate had grown larger. (K) Activation map demonstrating that the impulse originates from the nodal cell aggregate in the coculture. EB, embryoid body; MEA, multielectrode array; FP, field potential.

(Fig. 1A-D). To confirm that the cells forming the GATA6RFP cluster possess pacemaker potential, we isolated GATA6 nodal cells from EBs using a technique originally described by Field $[13,34]$. Based on the fact that cardiac pacemaking is accomplished by the electrical coupling of the specialized nodal cells with the atrial myocardium [35], we assessed whether GATA6 nodal cells were capable of coupling with and pacing atrial cardiomyocytes in culture. To accomplish this we cultured the GATA6 nodal cells as $3 \mathrm{D}$ aggregates to generate a critical mass of cells, and then added the aggregates to 2D monolayer cultures of HL-1 cells (Fig. 1E-K). HL-1 cells are an immortalized atrial cardiomyocyte cell line that spontaneously contracts and maintains a differentiated adult phenotype through 
multiple passages $[30,36]$. Using fluorescent calcium imaging we demonstrated through sequential frames that the GATA6 nodal cell aggregates produce spontaneous calcium transients that emit into the surrounding HL-1 cell monolayer (Fig. 1E$\mathrm{H})$. By analyzing MEA recordings of the cocultures we found that spontaneous depolarization waves were detected by electrodes corresponding to the nodal cell aggregate (Fig. 1I$\mathrm{J})$. The activation map of these cocultures confirmed that the pacemaker potential is generated by the GATA6 cell aggregate and propagates throughout the surrounding HL-1 cells (Fig. 1K).

\section{Spatial and temporal development of pacemaker tissues in EBs}

To delineate the cells of the developing SAN in EBs we used a mouse Shox $2^{\text {lacZ/+ }}$ ES cell line. The Shox 2 regulatory elements direct lac $Z$ expression to the putative developing SAN cells in EBs generated using the Shox $2^{\text {lacZ/+ }}$ ES cell line (Fig. 2A). By using a live $\beta$-galactosidase assay and fluorescent imaging, we demonstrated that Shox 2 cells appeared prior to the contracting myocytes within all of the EBs examined $(n>100)$. The lac $Z$ reporter expression in EBs appeared as early as day 6 of differentiation before the onset of any visible spontaneous contractions (Fig. 2B). The first contracting cells were detected in few EBs at day 8 of differentiation, and by day 14 of differentiation almost all EBs showed visible spontaneous contractions. We observed that the Shox2 cells within EBs developed as discrete clusters of cells as opposed to being diffusely scattered within the EBs (Fig. 2B, C). The organization of the Shox 2 cells in discrete clusters was observed in all of the EBs examined $(n>100)$. The Shox2 cell "cluster" or "node" within an EB is noncontracting. However, it is consistently detected adjacent to the contractile cardiac myocyte region in all spontaneously contracting EBs (Fig. 2C and Supplementary Video S1; Supplementary Data are available online at www.liebertpub .com/scd).

\section{Characterization of Shox2 cells within Shox2 ${ }^{\text {lacZ/+ }}$ EBs}

Automaticity of pacemaker cells is dependent on the presence of the hyperpolarization-activated cyclic nucleotidegated channel HCN4 $[10,37,38]$. To determine whether Shox 2 cells possess this pacemaker molecular signature, we stained Shox $2^{\text {lacZ/+ }}$ EBs with an in situ X-gal stain to mark the Shox 2 cells and coimmunostained for the pacemaker marker $\mathrm{HCN} 4$ and the cardiac contractile protein titin. We demonstrate that Shox2 cells express HCN4 but not titin. Shox2/HCN4-copositive, titin-negative cells were observed in a location directly adjacent to the titin-positive contracting cardiomyocytes within EBs (Fig. 2D, E). Based on the fact that nodal tissues express Cx45 to protect them from the inhibitory hyperpolarization influence of the surrounding atrial cardiomyocytes [39], we assessed the expression of Cx45 in Shox 2 cells. We demonstrate in Figure 2F and G that Shox 2 cells express $\mathrm{Cx} 45$. These data indicate that Shox 2 cells in EBs exhibit a SAN-like molecular phenotype, that is, Shox $2 / \mathrm{HCN} 4 / \mathrm{Cx} 45$-copositive, titin-negative $[40,41]$. To determine whether Shox2 cells are functionally coupled with the adjacent contracting cardiomyocytes, we performed

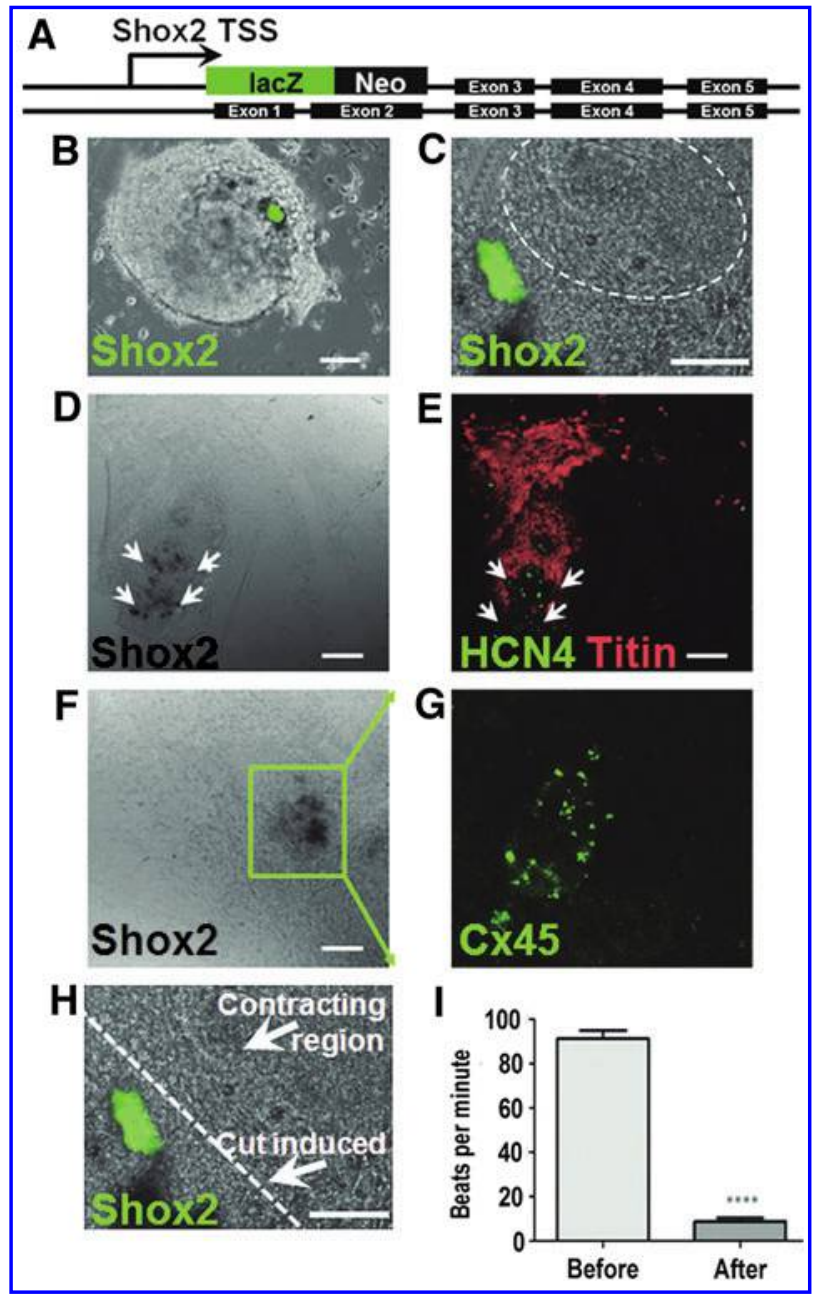

FIG. 2. Self-organized formation of cardiac pacemaker and contracting myocytes in EBs. (A) A diagram of the construct used to delineate developing SAN cells in EBs. A lacZ-neo cassette is knocked-into one of the Shox 2 alleles distal to the TSS, in the region of exons 1 and 2. (B, C) Representative live images of Shox $2^{\text {lacZ/+ }}$ EBs acquired using a fluorescence microscope following live fluorescein digalactoside staining. In (B), the EB is at day 7 of differentiation before the onset of contractions. In (C), the EB is at day 14 of differentiation and shows visible contractions. The Shox 2 cell cluster (green) is located adjacent to the contracting region (area surrounded by dashed circle). (C) Corresponds to Supplementary Video S1 demonstrating the location of the spontaneously contracting region. (D-G) Differential interference contrast and fluorescent confocal microscopic images of representative Shox $2^{\text {lacZ/+ }}$ EBs following in situ $\beta$-galactosidase staining and immunohistochemistry. (D, E) The white arrow heads point to the region of Shox2 cells within a representative Shox $2^{\text {lacZ/+ }}$ EB at day 14 of differentiation. The Shox 2 cells express HCN4 (green) and are located adjacent to titinpositive (red) working cardiomyocytes. (F) A green box surrounds the region of Shox 2 cells within a representative Shox $2^{\text {lacZ/+ }}$ EB at day 14 of differentiation. (G) A fluorescent image at an 8-zoom enlargement of the region inside the green box in (F), showing that Shox2 cells express Cx45. (H) A representative image showing the position where a cut (dashed line) was made in an EB. (I) Contraction rate in EBs before and after physically separating the lacZ-reporter region from the contracting region $(* * * * P<0.0001, n=11)$. Scale bar $=100 \mu \mathrm{m}$. SAN, sinoatrial node; TSS, transcription start site. 
experiments in which we physically separated the Shox 2 cell cluster from the adjacent spontaneously contracting region (Fig. 2H) as previously described [13]. Physical separation of the two regions resulted in a reduction in the rate of spontaneous contractions from $91.3 \pm 12.6$ (before separation) to $8.8 \pm 5.5$ contractions/min (after separation) (Fig. 2I). To exclude the possibility that tissue destruction within the EBs accounts for the reduction observed in contraction rates, we made cuts on the opposite side of the spontaneously contracting cardiomyocyte region away from the Shox2 cell cluster. None of the control cuts caused a change in contraction rates. These results establish that Shox 2 cells in EBs exhibit molecular and functional pacemaker characteristics.

\section{Shox2 knockout EBs exhibit hypoplasia of the SAN cell cluster}

To investigate the importance of Shox2 in the development of the putative SAN cells in EBs, we generated a Shox $2^{\text {lacZ/lac Z }}$ ES cell line (Fig. 3A-C). We assessed whether Shox2 null EBs

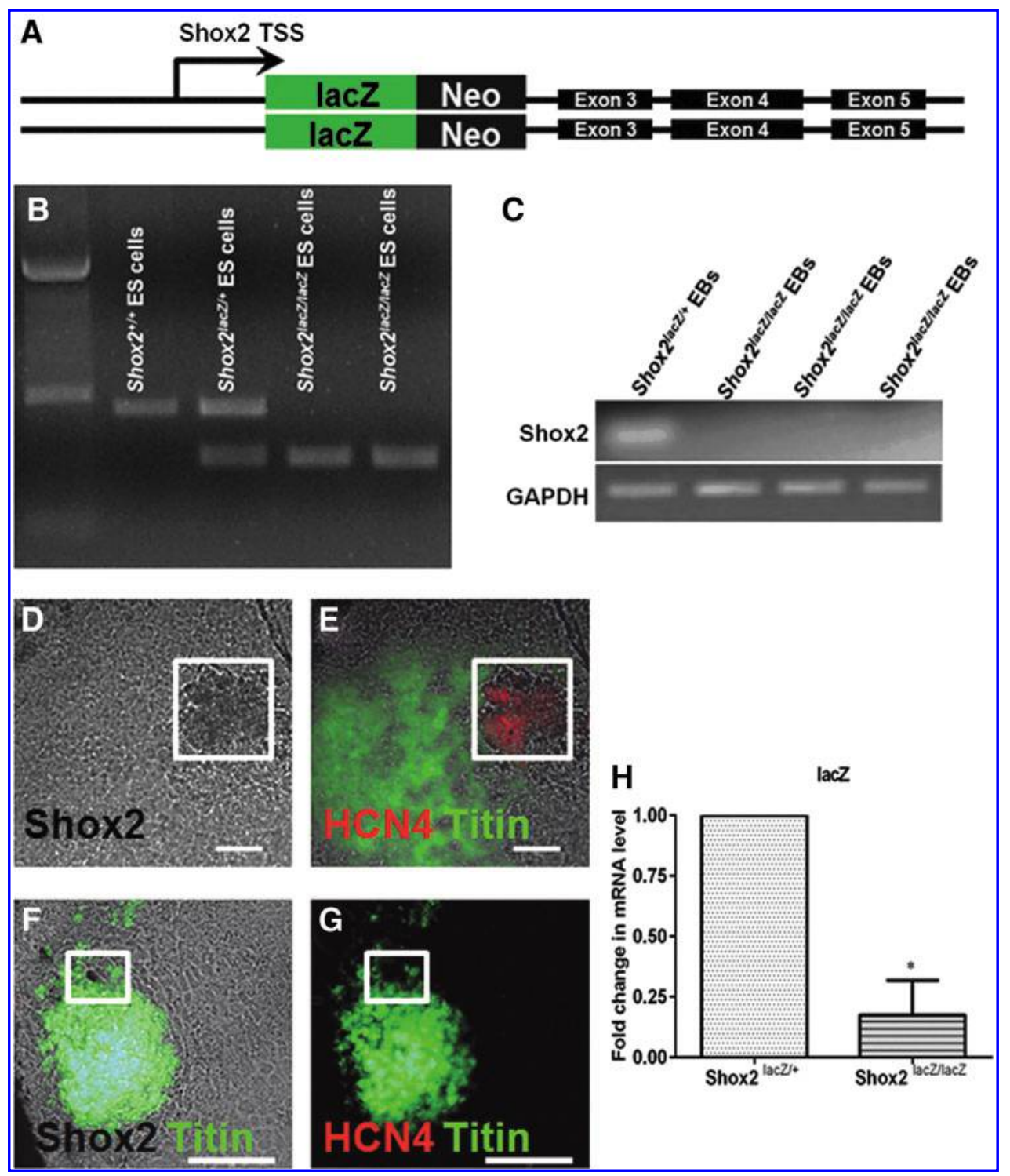

FIG. 3. Shox2 knockout EBs exhibit hypoplasia of the SAN cell cluster. (A) Diagram of Shox $2^{\text {lacz/lacz }}$ double knockin reporter. (B) Genotyping of Shox $2^{+/+}$(wild-type), Shox $2^{\text {lacZ/+ }}$, and Shox $2^{\text {lacZ/lacZ }}$ ES cells. Primers directed against the wildtype allele amplify a $520 \mathrm{bp}$ region within intron 1 and exon 2 of the Shox 2 gene while primers directed against the mutated allele amplify a $300 \mathrm{bp}$ region within the Neo region of the targeting vector. Separation of a $100 \mathrm{bp}$ ladder is shown in the leftmost lane of the gel. (C) qRT-PCR products separated by agarose gel electrophoresis show the presence of the Shox2 transcript in Shox $2^{\text {lac Z }+}+$ EBs, and its complete absence in three separate samples of Shox $2^{\text {lac } Z \text { /lacZ }}$ EBs. GAPDH was used as an internal control. Phase contrast and fluorescent images of a representative Shox $2^{\text {lacz/ }+}$ EB (D, E) and a representative Shox $2^{\text {lacZ/lacZ }} \mathrm{EB}(\mathbf{F}, \mathbf{G})$ both at day 14 of differentiation. Images acquired following in situ $\beta$-galactosidase staining and immunostaining for HCN4 (red) and cardiac contractile protein titin (green). The white boxes surround the lacZ region within the EB. (H) qRT-PCR analysis shows a reduction in lacZ transcript level in Shox2 ${ }^{\text {lacZ/lacz }}$ EBs compared with Sho $x 2^{\text {lacZ/+ }}$ EBs at day 14 of differentiation. GAPDH was used as an internal control $\left({ }^{*} P<0.05, n=3\right)$. Scale bar $=100 \mu \mathrm{m}$. ES, embryonic stem; qRT-PCR, quantitative reverse transcriptase-polymerase chain reaction; EB, embryoid body. 
exhibited a reduction in the number of differentiating SAN cells by performing in situ X-gal staining and immunohistochemical analysis of Shox $2^{\text {lacZ/lacz }}$ EBs and comparing them to Shox $2^{\text {lac } Z /+}$ EBs (Fig. 3D-G). We observed a marked reduction in the size of the lacZ-stained region adjacent to the titinpositive contracting cardiomyocyte region in Shox $2^{\text {lac Z/lacZ }}$ EBs compared with Shox $2^{\text {lacZ/+ }}$ EBs (Fig. 3D-G). The lacZ-stained region in Shox $2^{\text {lacZ/lac } Z}$ EBs showed marked reduction in HCN4 expression (Fig. 3G). When we compared mRNA levels of the lacZ transcript between Shox $2^{\text {lacZllac }}$ and Shox $2^{\text {lacZ/+ }}$ EBs, we observed a significant reduction in lacZ mRNA levels in the Shox $2^{\text {lac Z/lacZ }}$ EBs (Fig. $3 \mathrm{H}$ ).

\section{Shox2 knockout EBs exhibit slowed contraction rates}

The main function of the SAN is to initiate the heartbeat. Accordingly, we assessed the rate of spontaneous contractions in EBs as a determinant of SAN function $[10,38]$. The contraction rates were recorded in EBs from days 8 to 20 of differentiation. When contraction rates were compared in Shox $2^{+/+}$ EBs to Shox $2^{\text {lacZ/lacz }}$ EBs, there was initially no significant difference detected between both groups from days 8 to 11 of EB differentiation. Remarkably, starting from day 12 through day 20 (final time point at which contractions were counted), Shox $2^{\text {lacZlacz }}$ EBs showed significantly lower spontaneous contraction rates compared with Shox $2^{+/+}$EBs (Fig. 4A). The low spontaneous contraction rates detected in Shox $2^{\text {lac Z/lacZ }} \mathrm{EBs}$ indicate a failure of SAN maturation in these EBs.

\section{Pacemaker cell differentiation is altered in Shox2 knockout EBs}

To evaluate pacemaker and cardiac tissue development in Shox $2^{\text {lacZ/lacZ }}$ EBs, the mRNA levels of several molecular markers and transcription factors were analyzed using qRTPCR (Fig. 4B). These molecular markers included the pacemaker specific markers $\mathrm{HCN} 4$ and $\mathrm{Cx} 45$, which are essential for pacemaker-nodal function $[10,39,40]$. A downregulation in the levels of HCN4 and Cx45 was observed in Shox $2^{\text {lacZ/lacZ }}$ EBs (Fig. 4B). The fast conductance gap junctions, $C \times 40$ and Cx43, which are abundantly expressed in the myocardium and the conduction system but sparsely expressed in the SAN and AVN [42] were found to be upregulated in Shox $2^{\text {lacZ/lac Z }}$ EBs. The expression level of transcription factors Tbx2 and Tbx3, which have been reported to be involved in pacemaker tissue development [25,26,43-45], and transcription factors Tbx5 and Nkx2.5, which are known to activate the myocardial gene program $[9,46,47]$ were analyzed. We observed a downregulation in Tbx2 and Tbx3 levels, and an upregulation in Tbx5 and Nkx2.5 levels in Shox $2^{\text {lacZ/lacZ }}$ EBs (Fig. 4B). The mRNA level of BMP4, a downstream target of Shox2 [27], was downregulated in Shox $2^{\text {lacZ/lacZ }}$ EBs compared with Shox $2^{+/+}$ EBs (Fig. 4B). These observations indicate that Shox2 is required for activating the pacemaker gene program [41], and suppressing the working myocardial gene program in EBs.

\section{BMP4 rescues pacemaker tissue development in Shox $2^{\text {lacZ/lacZ }}$ EBs}

Shox 2 has previously been reported to directly activate the transcription of BMP4 in SAN cells by binding to the BMP4

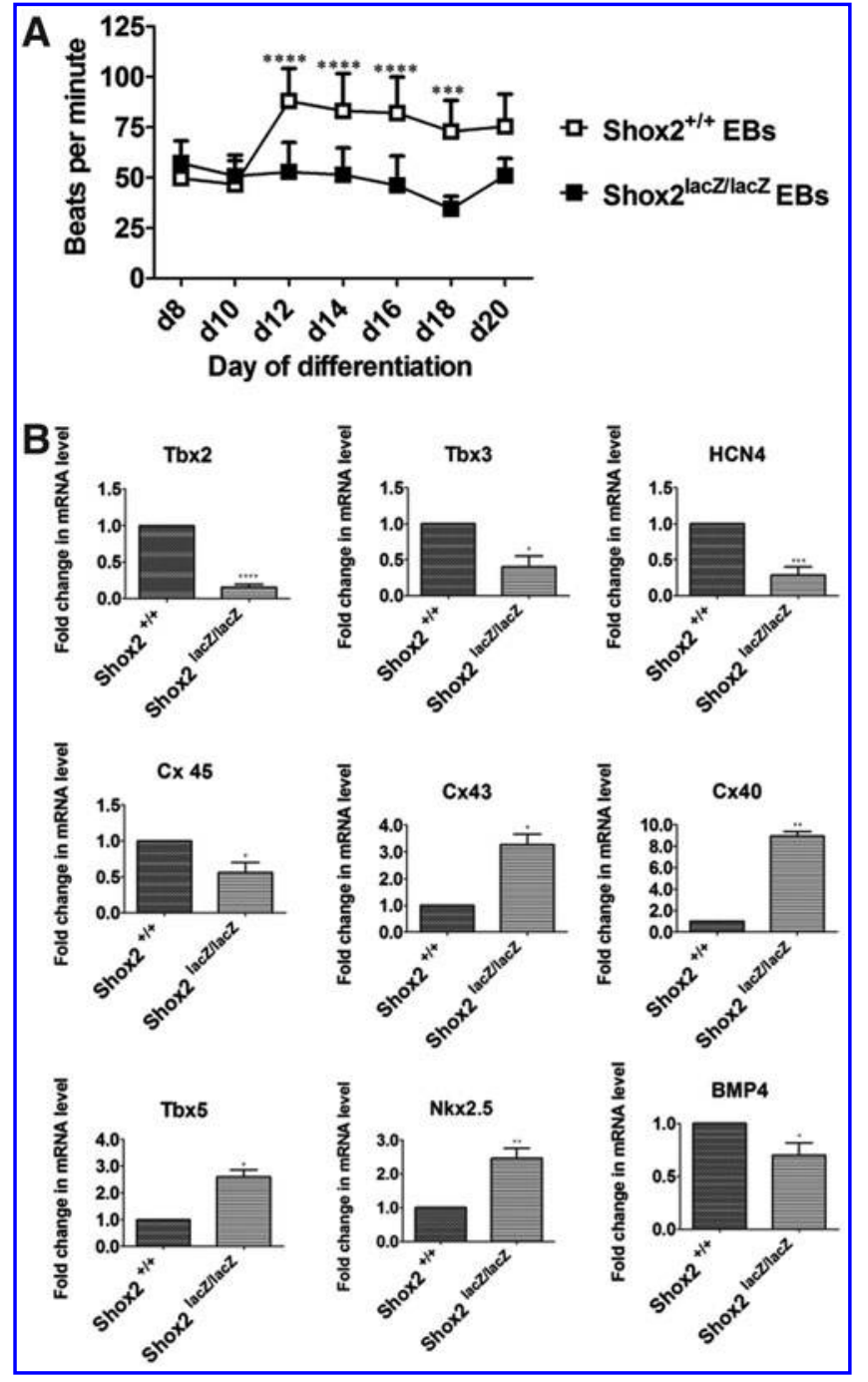

FIG. 4. Pacemaker cell differentiation is altered in Shox2 knockout EBs. (A) Contraction rates per minute of Shox $2^{\text {lac Z/lacZ }}$ EBs compared to Shox $2^{+/+}$EBs at different stages of differentiation, from days 8 to 20 of differentiation. (B) Bar graphs of Tbx2, Tbx3, HCN4, Cx45, Cx43, Cx40, Tbx5, Nkx2.5, and BMP4 mRNA transcript levels in Shox $2^{\text {lacz/lacz }}$ EBs compared to Sho $x 2^{+/+}$EBs at day 14 of differentiation. GAPDH was used as an internal control $\left({ }^{*} P<0.05\right.$ and ${ }^{* *} P<0.01,{ }^{* * *} P<0.001$ and $* * * * P<0.0001, n=5)$.

promoter [27]. Further, Shox $2^{-/-}$hearts lack BMP4 expression in the region of the SAN [27]. To investigate whether $\mathrm{BMP} 4$ plays a role in the pacemaker genetic pathway, we examined whether the phenotype observed in Shox $2^{\text {lac } Z / l a c Z}$ EBs can be rescued by adding BMP4 to the culture medium of EBs starting from day 6 of differentiation, which is the time of onset of Shox 2 expression (Fig. 2B). We observed that BMP4-treated Shox $2^{\text {lacZ/lacZ }}$ EBs exhibited higher spontaneous contraction rates $(74.5 \pm 23.4 \mathrm{bpm})$ compared with nontreated control EBs $(49.8 \pm 9.9 \mathrm{bpm})$ (Fig. 5A). We used qRT-PCR to compare relative expression of several molecular markers in Shox $2^{\text {lacZ/lac }}$ control and BMP4-treated EBs. Our results revealed an increase in HCN4, Cx45, Tbx2, and Tbx3 gene expression levels following BMP4 treatment (Fig. 5B). These 
FIG. 5. BMP4 rescues the phenotype in Shox 2 knockout EBs. (A) Contractions per minute in nontreated control Shox $2^{\text {lacZ/lacZ }}$ EBs and BMP4-treated Shox $2^{\text {lacz/lacz }}$ EBs, at day 16 of differentiation. (B) Bar graphs of Tbx2, Tbx3, HCN4, and Cx45 mRNA transcript levels in Shox $2^{\text {lacZ/lacZ }}$ EBs treated with BMP4 compared to nontreated control Shox $2^{\text {lacZ/lac }}$ EBs, at day 16 of differentiation. (C) Contractions per minute in nontreated control Sho $2^{+/+}$EBs and Noggin-treated Shox $2^{+/+}$EBs, at day 16 of differentiation. (D) Bar graphs of Tbx2, Tbx3, HCN4, and Cx45 mRNA transcript levels in Shox $2^{+/+}$EBs treated with Noggin compared to nontreated control Shox $2^{+/+}$EBs, at day 16 of differentiation. GAPDH was used as an internal control $\left({ }^{*} P<0.05\right.$ and ${ }^{* *} P<0.01$ and $* * * * P<0.0001, n=3)$.

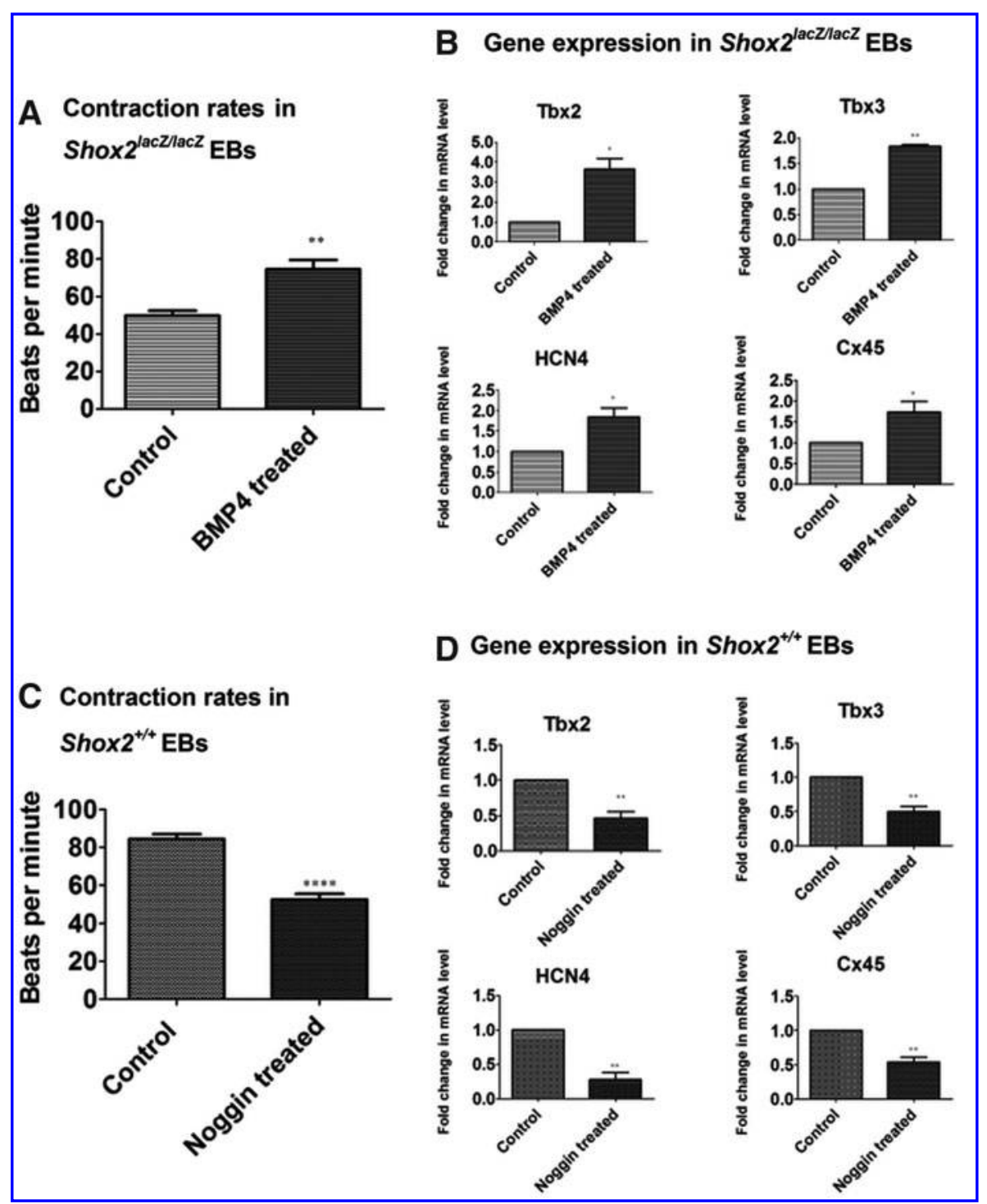

results show that when BMP4 was added to EBs in culture, it rescued pacemaker tissue development in Shox $2^{\text {lacZ/lacZ }}$ EBs. To validate the role of BMP4 signaling in pacemaker tissue development we examined the effect of Noggin on Shox $2^{+/+}$ EBs. Noggin is an extracellular inhibitor of BMP ligands with high affinity for BMP4 [48]. We added Noggin to Shox $2^{+/+}$ EBs in culture starting from day 6 of differentiation. We observed that Noggin-treated EBs exhibited lower spontaneous contraction rates $(52.5 \pm 23.5 \mathrm{bpm})$ compared with nontreated controls $(86.6 \pm 21.4 \mathrm{bpm})$ (Fig. 5C). When comparing qRT-PCR results of Shox $2^{+/+}$control and Noggintreated EBs, we observed a reduction in $\mathrm{HCN} 4, \mathrm{Cx} 45, \mathrm{Tbx} 2$, and Tbx3 gene expression levels to less than half their expression level in controls (Fig. 5D). This molecular phenotype is similar to that observed in the Shox 2 knockout EBs (Fig. 4B). Taken together, these data indicate that BMP4 plays an important role in the SAN pacemaker genetic pathway. To further validate the role of BMP4 in the pacemaker genetic pathway, we overexpressed Shox 2 in the HL-1 cell line. We used the HL-1 cell line because these cells exhibit a working cardiomyocyte phenotype [36]. HL-1 cells were transfected with an empty vector (control) or a Shox 2 over- expression vector. To inhibit BMP4 activity in HL-1 cells overexpressing Shox 2 , we added Noggin to the cultures. We assessed mRNA levels of $\mathrm{Tb} 33$, the pacemaker transcription factor that executes the pacemaker gene program [26]. The overexpression of Shox 2 in HL-1 cells resulted in an upregulation of Tbx3 expression levels compared with controls (Fig. 6). However, HL-1 cells overexpressing Shox 2 and cultured in the presence of Noggin treatment exhibited downregulation of Tbx3 expression level compared with HL-1 cells overexpressing Shox 2 in the absence of Noggin treatment (Fig. 6). These data suggest that BMP4 mediates the pacemaker genetic pathway by activating $\mathrm{Tbx} 3$ expression.

\section{Discussion}

Despite marked progress in deciphering the transcriptional regulation of cardiogenesis, our knowledge of the molecular genetic pathways controlling the formation and specification of the various components of the cardiac pacemaker and conduction system remain very limited. This is due in large part to the relative size and the technical difficulty in the direct isolation and analysis of these tissues 


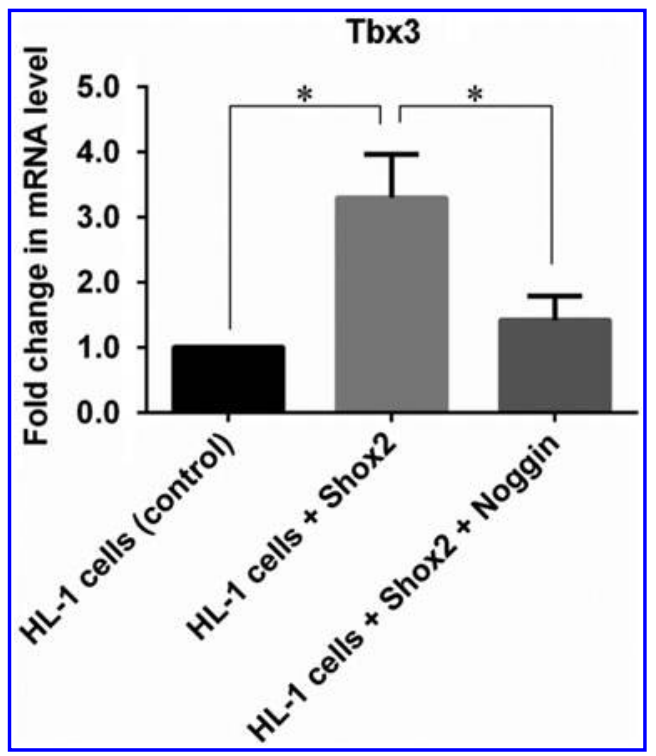

FIG. 6. BMP4 mediates the pacemaker gene pathway by activating Tbx3. A histogram plot of qRT-PCR data comparing Tbx3 transcript levels in HL-1 cells transfected with empty vector, HL-1 cells overexpressing Shox2, and HL-1 cells overexpressing Shox 2 and cultured in medium containing Noggin. GAPDH was used as an internal control. Shox2 overexpression in HL-1 cells resulted in an upregulation of Tbx3 mRNA level. HL-1 cells overexpressing Shox2 and treated with Noggin showed a downregulation of Tbx3 mRNA level $\left({ }^{*} P<0.05, n=5\right)$.

and cells for study. Therefore, an in vitro model system in which differentiating CCS components could be identified and studied as part of a functional tissue or as single cells would be invaluable. Pluripotent mouse ES cells grown as 3D EBs possess the ability to recapitulate major morphological, molecular, and electrophysiological features of the developing heart $[13,14,16,17,21]$. In this study, we investigated whether 3D ES cell cultures could be used as an in vitro model to study genetic regulation of the pacemaker gene program.

\section{Self-organization of the cardiac pacemaker and working myocytes in EBs}

Genetic markers have been utilized to delineate specific components of the CCS in vivo [5,49-54]. We have taken the approach of using genetic markers to delineate specific components of the CCS in in vitro 3D ES cell cultures (EBs). One of the genetic markers known to have an early pattern of expression is a $1.5 \mathrm{~kb}$ fragment of the GATA6 enhancer. This early cardiogenic enhancer becomes sequentially restricted to the posterior region of the heart field including the putative SAN region, and then to the AVC region after E10 in the mouse [49]. We used this minimal enhancer to direct RFP reporter expression to developing nodal cells in EBs using a GATA6-RFP construct [13]. Our MEA data demonstrate that a pacemaker electrical current originates from a localized group of cells in the RFP reporter region of the EB, and propagates into the contracting region (Fig. 1A-D). These data are in concordance with a number of studies that showed the formation of a functional syncytium of cardio- myocytes in spontaneously contracting EBs $[20,55,56]$. Moreover, Banach et al. showed that electrical activity and cardiomyocyte development in EBs closely follows the development of the mouse embryonic heart [32]. Taken together, these data suggest that EBs can be used as in vitro models to study the differentiation of electrical activity in embryonic cardiomyocytes. Based on the fact that calciumdependent depolarizations play a major role in the generation of cardiac pacemaker activity [57], we used a fluorescent calcium-sensitive dye to assess functional coupling and excitation propagation ability of GATA6 cells. We confirm that our nodal-like (GATA6) cells isolated from EBs function as pacemaker cells (Fig. 1E-K). We show this through coculture experiments that demonstrate the emission of calcium sparks from the 3D nodal cell aggregates into the surrounding monolayer of HL-1 cells (Fig. 1E-H). We also show this through our MEA data of cocultures that demonstrate that ES cell-derived nodal-like GATA6 cells exhibit spontaneous diastolic depolarizations characteristic of pacemaker cells [31].

To assess the ability of the cardiac pacemaker and contracting myocytes to self-organize in 3D ES cell cultures, we selected a genetic marker that will specifically delineate the main pacemaker component of the CCS, the SAN. We established using a Shox $2^{\text {lacZ/ }}+$ EB model that Shox 2 cells appeared first followed by the development of the working cardiomyocytes (spontaneous contractions) (Fig. 2B, C). This temporal order of development in EBs is similar to the temporal organization of these components during in vivo embryogenesis where in the developing heart tube the SAN is the first functional component to form by E8.5 [58]. This is followed by the formation of the four heart chambers and the distal components of the CCS by E13 to E14 [59]. Additionally, the Shox 2 cells formed in clusters or "nodes" that were spatially organized and functionally connected with contracting cardiomyocytes within EBs (Fig. 2C-I). Our findings indicate the self-organized formation of the cardiac pacemaker and contracting myocytes in EBs. Recent studies using mouse and human ES cells cultured as EB aggregates demonstrated a high degree of self-organized formation of specialized tissues and structures that recapitulate spatial and temporal aspects of early developments [60-64]. ten Berge et al. showed the establishment of anterior-posterior axis polarity and a primitive streak-like region in EBs [64]. Using serum-free culture conditions, Eiraku et al. demonstrated that EBs form highly reproducible complex structures that resemble corticogenesis in embryos [62]. The same group was able to optimize their culture conditions to induce EBs to self-organize into an optic cup containing lightsensitive cells and neurons [61]. In another study, EBs were induced to reproducibly form Rathke's pouch (anterior pituitary gland precursor)-like structures from which all five hormone-secreting cells of the anterior pituitary were observed to differentiate and secrete their respective hormones [63]. All these studies provide strong evidence that in EBs specialized tissues and structures do form, and that spatial and temporal aspects of their development are recapitulated.

\section{Shox2 is essential for the development of pacemaker cells in EBs}

In this study we have taken the novel approach of investigating whether ES cells in 3D cultures can be used to study 
the developmental regulation of the specialized pacemaker tissues of the heart. Shox 2 is known to activate the SAN gene program by inhibiting the expression of the cardiac transcription factor $\mathrm{Nkx2.5}$, and upregulating the expression of HCN4 and Cx45 $[6,23,24]$. In our Shox $2^{\text {lacZ/+ }}$ EB model we show that Shox 2 cells express HCN4 and Cx45, but not the cardiac contractile protein titin (Fig. 2D-G). This phenotype is characteristic of SAN cells $[6,40]$. To investigate whether Shox 2 is essential for SAN development in EBs, we generated a Shox $2^{\text {lacZ/lacZ }}$ ES cell line (Fig. 3A). We demonstrate that in the Shox $2^{\text {lac } Z / l a c Z}$ EB model the SAN cell cluster is hypoplastic compared with the Shox $2^{\text {lacZ/+ }}$ EB (Fig. 3D-H). This phenotype resembles that of Shox $2^{-/-}$hearts. Researchers reported that the reduction in the size of the SAN area in Sho $x 2^{-/-}$hearts in vivo is due to decreased cell proliferation in this region [6,23]. An alternative explanation for the reduction in SAN cells in Shox $2^{\text {lacZ/lacZ }}$ EBs is that Shox2 could be required for its own expression. The hypoplasia of the SAN cell cluster in Shox $2^{\text {lac Z/lacZ }}$ EBs was associated with a significant reduction in the rate of contraction of the neighboring cardiomyocytes (Fig. 4A). This is consistent with the observation that the SAN hypoplasia in Shox $2^{-/-}$hearts is associated with a reduced heartbeat [6]. The reduction in contraction rates in Shox $2^{\text {lacZ/lacZ }}$ EBs was observed after day 11 of differentiation (Fig. 4A), which is similar to what has been previously reported in Shox $2^{-1-}$ embryonic mouse hearts that show a reduction in beat rate after E10.5 [6]. Shox $2^{\text {lacZllacz }}$ EBs showed a reduction in Tbx2, Tbx3, HCN4, and Cx45 transcript levels (Fig. 4B). These molecular markers are known for their vital role in SAN maturation and function. HCN4 is essential for spontaneous diastolic depolarizations characteristic of pacemaker cells [10,37], and $\mathrm{HCN}^{-/-}$hearts exhibit a reduced beat rate $[10,38]$. It is interesting to note that a study using a selective pharmacological blocker of the HCN4 channel reported a reduction in the spontaneous contraction rates in EBs consistent with the reductions we observed in our Shox $2^{\text {lacZ/lacZ }}$ EB model (Fig. 5A) [65]. Accordingly, the reduction in contraction rates in Shox $2^{\text {lacZ/lacZ }} \mathrm{EBs}$ is due to the markedly reduced HCN4 levels detected in our immunohistochemical and qRT-PCR analyses (Figs. 3F, G and 4B). The fold change in gene expression for some of the genes examined was higher than others (Fig. 4B). This could be due to some noncell autonomous effects caused by the loss of Shox 2 expression. Overall, our data indicate that Shox $2^{\text {lacZ/lacZ }}$ EBs exhibit a phenotype comparable to Shox $2^{-1-}$ in vivo hearts, and that Shox2 is essential for the development of pacemaker cells in EBs.

\section{BMP4 plays an important role in the pacemaker gene program}

$\mathrm{BMP} 4$, a member of the transforming growth factor- $\beta$ family, was downregulated in Shox $2^{\text {lacz/lac }}$ EBs compared with controls (Fig. 4B). BMP4 is a direct downstream target of Shox2 as demonstrated in chromatin immunoprecipitation assays, luciferase reporter assays, and gain-of-function and lossof-function experiments [27]. To investigate whether BMP4 plays a role in the SAN pacemaker genetic pathway, we added BMP4 to Shox $2^{\text {lac Z/lacZ }}$ EBs to observe whether it can rescue the phenotype. The addition of BMP4 to Shox $2^{\text {lacZ/lacZ }}$ EBs resulted in an increase in the rate of spontaneous contractions and an increase in pacemaker-specific molecular markers compared to nontreated controls (Fig. 5A, B). Further when we added Noggin, a potent BMP4 inhibitor, to Sho $x 2^{+/+}$EBs we observed a phenotype consistent with Shox $2^{\text {lacZ/lacZ }}$ in EBs. This included reduction in spontaneous contraction rates and a reduction in pacemaker-specific molecular markers (Fig. 5C, D). When we overexpressed Shox 2 in HL-1 cells, we observed an increase in Tbx3 expression (Fig. 6). This Shox2-induced increase in Tbx3 expression was inhibited by the addition of Noggin treatments to the culture media, indicating the importance of BMP4 in the pacemaker gene pathway. The expression of T-box transcription factors has been reported to be associated with BMP signaling during organogenesis [66-68]. Homeodomain transcription factors function differently based on the cellular context and based on their associated cofactors. It is very likely that other cofactors are involved in the Shox2activated SAN genetic pathway. The in vitro EB model that we have described in this article will be an invaluable tool for studying the molecular pathways regulating the development of the cardiac pacemaker tissues.

\section{Acknowledgments}

We are grateful to Dr. YiPing Chen (Tulane University) for CJ-7 ES cells, Shox $2^{\text {lacZ/+ }}$ ES cells, and the pIRES-Shox2DsRED plasmid; and to Dr. Charles Nichols (LSUHSC, New Orleans) for training and access to the confocal microscope.

\section{Author Disclosure Statement}

No competing financial interests exist.

\section{References}

1. Keith A and M Flack. (1907). The form and nature of the muscular connections between the primary divisions of the vertebrate heart. J Anat Physiol 41:172-189.

2. de Carvalho A and D de Almeida. (1960). Spread of activity through the atrioventricular node. Circ Res 8:801-809.

3. Watanabe $Y$ and LS Dreifus. (1968). Sites of impulse formation within the atrioventricular junction of the rabbit. Circ Res 22:717-727.

4. Dobrzynski H, VP Nikolski, AT Sambelashvili, ID Greener, M Yamamoto, MR Boyett and IR Efimov. (2003). Site of origin and molecular substrate of atrioventricular junctional rhythm in the rabbit heart. Circ Res 93:1102-1110.

5. Kupershmidt S, T Yang, ME Anderson, A Wessels, KD Niswender, MA Magnuson and DM Roden. (1999). Replacement by homologous recombination of the minK gene with lacZ reveals restriction of $\operatorname{minK}$ expression to the mouse cardiac conduction system. Circ Res 84:146-152.

6. Espinoza-Lewis RA, L Yu, F He, H Liu, R Tang, J Shi, X Sun, JF Martin, D Wang, J Yang and Y Chen. (2009). Shox2 is essential for the differentiation of cardiac pacemaker cells by repressing Nkx2-5. Dev Biol 327:376-385.

7. Simon AM, DA Goodenough and DL Paul. (1998). Mice lacking connexin40 have cardiac conduction abnormalities characteristic of atrioventricular block and bundle branch block. Curr Biol 8:295-298.

8. Chen F, H Kook, R Milewski, AD Gitler, MM Lu, J Li, R Nazarian, R Schnepp, K Jen, et al. (2002). Hop is an unusual homeobox gene that modulates cardiac development. Cell 110:713-723.

9. Bruneau BG, G Nemer, JP Schmitt, F Charron, L Robitaille, S Caron, DA Conner, M Gessler, M Nemer, CE Seidman and 
JG Seidman. (2001). A murine model of Holt-Oram syndrome defines roles of the T-box transcription factor Tbx 5 in cardiogenesis and disease. Cell 106:709-721.

10. Baruscotti M, A Bucchi, C Viscomi, G Mandelli, G Consalez, T Gnecchi-Rusconi, N Montano, KR Casali, S Micheloni, A Barbuti and D DiFrancesco. (2011). Deep bradycardia and heart block caused by inducible cardiac-specific knockout of the pacemaker channel gene Hcn4. Proc Natl Acad Sci U S A 108:1705-1710.

11. Kumai M, K Nishii, K Nakamura, N Takeda, M Suzuki and Y Shibata. (2000). Loss of connexin 45 causes a cushion defect in early cardiogenesis. Development 127:3501-3512.

12. Maltsev VA, J Rohwedel, J Hescheler and AM Wobus. (1993). Embryonic stem cells differentiate in vitro into cardiomyocytes representing sinusnodal, atrial and ventricular cell types. Mech Dev 44:41-50.

13. White SM and WC Claycomb. (2005). Embryonic stem cells form an organized, functional cardiac conduction system in vitro. Am J Physiol Heart Circ Physiol 288:H670-H679.

14. Boheler KR, DG Crider, Y Tarasova and VA Maltsev. (2005). Cardiomyocytes derived from embryonic stem cells. Methods Mol Med 108:417-435.

15. Zwi L, O Caspi, G Arbel, I Huber, A Gepstein, IH Park and L Gepstein. (2009). Cardiomyocyte differentiation of human induced pluripotent stem cells. Circulation 120:1513-1523.

16. Wei H, O Juhasz, J Li, YS Tarasova and KR Boheler. (2005). Embryonic stem cells and cardiomyocyte differentiation: phenotypic and molecular analyses. J Cell Mol Med 9:804-817.

17. Boheler KR, J Czyz, D Tweedie, HT Yang, SV Anisimov and AM Wobus. (2002). Differentiation of pluripotent embryonic stem cells into cardiomyocytes. Circ Res 91:189-201.

18. Kehat I, D Kenyagin-Karsenti, M Snir, H Segev, M Amit, A Gepstein, E Livne, O Binah, J Itskovitz-Eldor and L Gepstein. (2001). Human embryonic stem cells can differentiate into myocytes with structural and functional properties of cardiomyocytes. J Clin Invest 108:407-414.

19. Wobus AM, J Rohwedel, V Maltsev and J Hescheler. (1995). Development of cardiomyocytes expressing cardiac-specific genes, action potentials, and ionic channels during embryonic stem cell-derived cardiogenesis. Ann N Y Acad Sci 752:460-469.

20. Kehat I, A Gepstein, A Spira, J Itskovitz-Eldor and L Gepstein. (2002). High-resolution electrophysiological assessment of human embryonic stem cell-derived cardiomyocytes: a novel in vitro model for the study of conduction. Circ Res 91:659-661.

21. Hescheler J, BK Fleischmann, S Lentini, VA Maltsev, J Rohwedel, AM Wobus and K Addicks. (1997). Embryonic stem cells: a model to study structural and functional properties in cardiomyogenesis. Cardiovasc Res 36:149-162.

22. Maltsev VA, AM Wobus, J Rohwedel, M Bader and J Hescheler. (1994). Cardiomyocytes differentiated in vitro from embryonic stem cells developmentally express cardiacspecific genes and ionic currents. Circ Res 75:233-244.

23. Blaschke RJ, ND Hahurij, S Kuijper, S Just, LJ Wisse, K Deissler, T Maxelon, K Anastassiadis, J Spitzer, et al. (2007). Targeted mutation reveals essential functions of the homeodomain transcription factor Shox 2 in sinoatrial and pacemaking development. Circulation 115:1830-1838.

24. Espinoza-Lewis RA, H Liu, C Sun, C Chen, K Jiao and Y Chen. (2011). Ectopic expression of Nkx2.5 suppresses the formation of the sinoatrial node in mice. Dev Biol 356:359-369.

25. Hoogaars WM, A Engel, JF Brons, AO Verkerk, FJ de Lange, LY Wong, ML Bakker, DE Clout, V Wakker, et al. (2007). $\mathrm{Tbx} 3$ controls the sinoatrial node gene program and imposes pacemaker function on the atria. Genes Dev 21:1098-1112.
26. Bakker ML, GJ Boink, BJ Boukens, AO Verkerk, $M$ van den Boogaard, AD den Haan, WM Hoogaars, HP Buermans, JM de Bakker, et al. (2012). T-box transcription factor TBX3 reprogrammes mature cardiac myocytes into pacemaker-like cells. Cardiovasc Res 94:439-449.

27. Puskaric S, S Schmitteckert, AD Mori, A Glaser, KU Schneider, BG Bruneau, RJ Blaschke, H Steinbeisser and G Rappold. (2010). Shox 2 mediates Tbx 5 activity by regulating Bmp4 in the pacemaker region of the developing heart. Hum Mol Genet 19:4625-4633.

28. Lam ML, SI Hashem and WC Claycomb. (2011). Embryonic stem cell-derived cardiomyocytes harbor a subpopulation of niche-forming Sca-1+ progenitor cells. Mol Cell Biochem 349:69-76.

29. Livak KJ and TD Schmittgen. (2001). Analysis of relative gene expression data using real-time quantitative PCR and the 2(-Delta Delta C(T)) method. Methods 25:402-408.

30. White SM, PE Constantin and WC Claycomb. (2004). Cardiac physiology at the cellular level: use of cultured HL-1 cardiomyocytes for studies of cardiac muscle cell structure and function. Am J Physiol Heart Circ Physiol 286:H823H829.

31. Halbach M, U Egert, J Hescheler and K Banach. (2003). Estimation of action potential changes from field potential recordings in multicellular mouse cardiac myocyte cultures. Cell Physiol Biochem 13:271-284.

32. Banach K, MD Halbach, P Hu, J Hescheler and U Egert. (2003). Development of electrical activity in cardiac myocyte aggregates derived from mouse embryonic stem cells. Am J Physiol Heart Circ Physiol 284:H2114-H2123.

33. Mortensen RM. (1993). Double knockouts. Production of mutant cell lines in cardiovascular research. Hypertension 22:646-651.

34. Klug MG, MH Soonpaa, GY Koh and LJ Field. (1996). Genetically selected cardiomyocytes from differentiating embronic stem cells form stable intracardiac grafts. I Clin Invest 98:216-224.

35. James TN. (2003). Structure and function of the sinus node, AV node and his bundle of the human heart: part IIfunction. Prog Cardiovasc Dis 45:327-360.

36. Claycomb WC, NA Lanson Jr, BS Stallworth, DB Egeland, JB Delcarpio, A Bahinski and NJ Izzo Jr. (1998). HL-1 cells: a cardiac muscle cell line that contracts and retains phenotypic characteristics of the adult cardiomyocyte. Proc Natl Acad Sci U S A 95:2979-2984.

37. Bucchi A, A Barbuti, D Difrancesco and M Baruscotti. (2012). Funny current and cardiac rhythm: insights from HCN knockout and transgenic mouse models. Front Physiol 3:240.

38. Stieber J, S Herrmann, S Feil, J Loster, R Feil, M Biel, F Hofmann and A Ludwig. (2003). The hyperpolarizationactivated channel HCN4 is required for the generation of pacemaker action potentials in the embryonic heart. Proc Natl Acad Sci U S A 100:15235-15240.

39. Verheijck EE, MJ van Kempen, M Veereschild, J Lurvink, HJ Jongsma and LN Bouman. (2001). Electrophysiological features of the mouse sinoatrial node in relation to connexin distribution. Cardiovasc Res 52:40-50.

40. Yamamoto M, H Dobrzynski, J Tellez, R Niwa, R Billeter, H Honjo, I Kodama and MR Boyett. (2006). Extended atrial conduction system characterised by the expression of the HCN4 channel and connexin45. Cardiovasc Res 72:271-281.

41. Christoffels VM, GJ Smits, A Kispert and AF Moorman. (2010). Development of the pacemaker tissues of the heart. Circ Res 106:240-254. 
42. Boyett MR, H Honjo and I Kodama. (2000). The sinoatrial node, a heterogeneous pacemaker structure. Cardiovasc Res 47:658-687.

43. Christoffels VM, WM Hoogaars, A Tessari, DE Clout, AF Moorman and M Campione. (2004). T-box transcription factor Tbx2 represses differentiation and formation of the cardiac chambers. Dev Dyn 229:763-770.

44. Singh R, WM Hoogaars, P Barnett, T Grieskamp, MS Rana, H Buermans, HF Farin, M Petry, T Heallen, et al. (2012). Tbx2 and Tbx3 induce atrioventricular myocardial development and endocardial cushion formation. Cell Mol Life Sci 69:1377-1389.

45. Hoogaars WM, A Tessari, AF Moorman, PA de Boer, J Hagoort, AT Soufan, M Campione and VM Christoffels. (2004). The transcriptional repressor $\mathrm{Tb} 33$ delineates the developing central conduction system of the heart. Cardiovasc Res 62:489-499.

46. Bruneau BG, M Logan, N Davis, T Levi, CJ Tabin, JG Seidman and CE Seidman. (1999). Chamber-specific cardiac expression of Tbx5 and heart defects in Holt-Oram syndrome. Dev Biol 211:100-108.

47. Durocher D, CY Chen, A Ardati, RJ Schwartz and M Nemer. (1996). The atrial natriuretic factor promoter is a downstream target for Nkx-2.5 in the myocardium. Mol Cell Biol 16:4648-4655.

48. Zimmerman LB, JM De Jesus-Escobar and RM Harland. (1996). The Spemann organizer signal noggin binds and inactivates bone morphogenetic protein 4. Cell 86:599-606.

49. Davis DL, AV Edwards, AL Juraszek, A Phelps, A Wessels and JB Burch. (2001). A GATA-6 gene heart-region-specific enhancer provides a novel means to mark and probe a discrete component of the mouse cardiac conduction system. Mech Dev 108:105-119.

50. He CZ and JB Burch. (1997). The chicken GATA-6 locus contains multiple control regions that confer distinct patterns of heart region-specific expression in transgenic mouse embryos. J Biol Chem 272:28550-28556.

51. Munshi NV, J McAnally, S Bezprozvannaya, JM Berry, JA Richardson, JA Hill and EN Olson. (2009). Cx30.2 enhancer analysis identifies Gata4 as a novel regulator of atrioventricular delay. Development 136:2665-2674.

52. Viswanathan S, JB Burch, GI Fishman, IP Moskowitz and DW Benson. (2007). Characterization of sinoatrial node in four conduction system marker mice. J Mol Cell Cardiol 42:946-953.

53. Wessels A, A Phelps, TC Trusk, DL Davis, AV Edwards, JB Burch and AL Juraszek. (2003). Mouse models for cardiac conduction system development. Novartis Found Symp 250:44-59; discussion 59-67, 276-279.

54. Adamo RF, CL Guay, AV Edwards, A Wessels and JB Burch. (2004). GATA-6 gene enhancer contains nested regulatory modules for primary myocardium and the embedded nascent atrioventricular conduction system. Anat Rec A Discov Mol Cell Evol Biol 280:1062-1071.

55. Kehat I, L Khimovich, O Caspi, A Gepstein, R Shofti, G Arbel, I Huber, J Satin, J Itskovitz-Eldor and L Gepstein. (2004). Electromechanical integration of cardiomyocytes derived from human embryonic stem cells. Nat Biotechnol 22:1282-1289.

56. Satin J, I Kehat, O Caspi, I Huber, G Arbel, I Itzhaki, J Magyar, EA Schroder, I Perlman and L Gepstein. (2004). Mechanism of spontaneous excitability in human embryonic stem cell derived cardiomyocytes. J Physiol 559:479-496.
57. Mangoni ME, B Couette, E Bourinet, J Platzer, D Reimer, J Striessnig and J Nargeot. (2003). Functional role of L-type Cav1.3 Ca2 + channels in cardiac pacemaker activity. Proc Natl Acad Sci U S A 100:5543-5548.

58. Nishii K and Y Shibata. (2006). Mode and determination of the initial contraction stage in the mouse embryo heart. Anat Embryol (Berl) 211:95-100.

59. Christoffels VM, PE Habets, D Franco, M Campione, F de Jong, WH Lamers, ZZ Bao, S Palmer, C Biben, RP Harvey and AF Moorman. (2000). Chamber formation and morphogenesis in the developing mammalian heart. Dev Biol 223:266-278.

60. Eiraku M and Y Sasai. (2011). Mouse embryonic stem cell culture for generation of three-dimensional retinal and cortical tissues. Nat Protoc 7:69-79.

61. Eiraku M, N Takata, H Ishibashi, M Kawada, E Sakakura, S Okuda, K Sekiguchi, T Adachi and Y Sasai. (2011). Selforganizing optic-cup morphogenesis in three-dimensional culture. Nature 472:51-56.

62. Eiraku M, K Watanabe, M Matsuo-Takasaki, M Kawada, S Yonemura, M Matsumura, T Wataya, A Nishiyama, K Muguruma and Y Sasai. (2008). Self-organized formation of polarized cortical tissues from ESCs and its active manipulation by extrinsic signals. Cell Stem Cell 3:519-532.

63. Suga H, T Kadoshima, M Minaguchi, M Ohgushi, M Soen, $\mathrm{T}$ Nakano, N Takata, T Wataya, K Muguruma, et al. (2011). Self-formation of functional adenohypophysis in threedimensional culture. Nature 480:57-62.

64. ten Berge D, W Koole, C Fuerer, M Fish, E Eroglu and R Nusse. (2008). Wnt signaling mediates self-organization and axis formation in embryoid bodies. Cell Stem Cell 3:508-518.

65. Qu Y, GM Whitaker, L Hove-Madsen, GF Tibbits and EA Accili. (2008). Hyperpolarization-activated cyclic nucleotidemodulated ' $\mathrm{HCN}$ ' channels confer regular and faster rhythmicity to beating mouse embryonic stem cells. J Physiol 586:701-716.

66. Behesti H, JK Holt and JC Sowden. (2006). The level of BMP4 signaling is critical for the regulation of distinct T-box gene expression domains and growth along the dorso-ventral axis of the optic cup. BMC Dev Biol 6:62.

67. Yamada M, JP Revelli, G Eichele, M Barron and RJ Schwartz. (2000). Expression of chick Tbx-2, Tbx-3, and Tbx-5 genes during early heart development: evidence for BMP2 induction of Tbx2. Dev Biol 228:95-105.

68. Lee JM, JY Kim, KW Cho, MJ Lee, SW Cho, Y Zhang, SK Byun, CK Yi and HS Jung. (2007). Modulation of cell proliferation during palatogenesis by the interplay between Tbx3 and Bmp4. Cell Tissue Res 327:285-292.

Address correspondence to: Dr. William C. Claycomb Department of Biochemistry and Molecular Biology Louisiana State University Health Sciences Center 1901 Perdido Street New Orleans, LA 70112

E-mail: wclayc@lsuhsc.edu

Received for publication March 5, 2013

Accepted after revision June 13, 2013 Prepublished on Liebert Instant Online XXXX XX, XXXX 